\title{
A AUTONOMIA DA PERÍCIA CRIMINAL E A PRODUÇÃO DE PROVAS FACE ÀS GARANTIAS CONSTITUCIONAIS
}

\section{THE AUTONOMY OF CRIMINAL FORENSICS AND THE PRODUCTION OF PROOF CONCERNING CONSTITUTIONAL GUARANTEES}

\section{Francisco dos Santos Oliveira Soares ${ }^{1}$}

\section{RESUMO}

O presente artigo tem por objetivo discutir a problemática da produção das provas não repetíveis sem a observância de garantias constitucionais. Utiliza-se de uma visão garantista para apresentar o problema da investigação policial e da restrição de direitos com fundamento no mistifório de elementos oriundos da fase inquisitiva e processual. Propõe um novo modelo de produção das provas periciais, baseado na separação do órgão pericial da estrutura policial, bem como da exclusão total do inquérito policial dos autos do processo. Para tanto, faz-se uso do método dedutivo e fundamenta-se em doutrina consagrada na matéria processual penal para demonstrar que o sistema brasileiro necessita urgentemente de modificações quanto ao modelo de investigação, de produção da prova pericial e, principalmente, adequação das normas do Código de Processo Penal às garantias essenciais a um Estado Democrático de Direito. Como resultado, verifica-se que a perícia criminal deve alcançar o patamar de instituição autônoma, com independência funcional e financeira, constituindo verdadeiramente função essencial à Justiça, de forma a possibilitar um processo justo, que assegure às partes todas as garantias constitucionais relacionadas à produção da prova pericial.

Palavras-chaves: Garantias constitucionais; Inquérito policial; Perícia Criminal; Produção de prova.

\section{ABSTRACT}

This article aims to discuss the problem of producing non-repeatable evidence without observing constitutional guarantees. A guarantor view is used to present the problem of police investigation and restriction of rights based on the mixture of elements from the inquisitive and procedural phase. A new model is proposed to produce criminal forensic evidence based on the separation of the forensic body from the police structure and as well as the complete exclusion of the police inquiry from the file. To this end, the deductive method is used and based on established doctrine in criminal procedural matters to demonstrate that the Brazilian system urgently needs modifications regarding the investigation model, the production of criminal forensic evidence and, mainly, the adequacy of the norms of Criminal Procedure Code to the essential guarantees to a

1 Graduado em Ciências Biológicas pela Faculdade do Médio Parnaíba (FAMEP). Graduando em Direito pela Universidade Federal do Tocantins (UFT). Perito Criminal na Polícia Científica do Tocantins. Palmas (TO), Brasil. CV Lattes: http://lattes.cnpq.br/8206998135248795. E-mail: francisco.soares@uft.edu.br. ORCID no 0000-0003-4541-9975. 
democratic Rechtsstaat. As a result, it can be perceived that the criminal forensics must reach the level of an autonomous institution, functionally and financially independent, truly constituting an essential function for the Justice, in order to enable a fair process, which guarantees to the parties all the constitutional guarantees related to the production of forensic evidence.

Keywords: Constitutional guarantees; Police Inquiry; Criminal Forensics; Proof production.

\section{INTRODUÇÃO}

Com a promulgação da Constituição da República Federativa do Brasil 1988 (CRFB/88) ocorreram profundas mudanças na interpretação de muitas normas jurídicas que existiam no país, principalmente as relacionadas à matéria criminal. Com isso, iniciou-se uma difícil convivência de normas de caráter criminal extremamente punitivistas com normas constitucionais de largo espectro humanista.

As garantias presentes no ordenamento jurídico, principalmente em nível de lei maior, são formas de viabilizar o Estado Democrático de Direito, para isso, é essencial que todos os atos e normas estejam em plena sintonia com elas.

O art. 5 da CRFB/88 abre o Título II - Dos Direitos e Garantias Fundamentais e apresenta verdadeiros princípios norteadores dos tratos jurídicos que ocorrem sob a égide e a supremacia da lei fundamental, dentre eles, o da legalidade (art. 5으. II), do

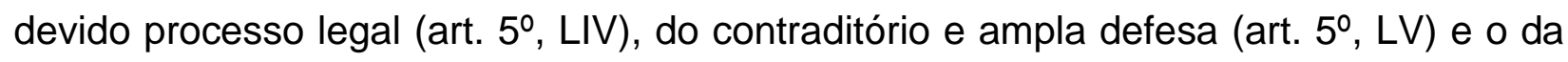
presunção de inocência (art. 5ำ, LVIII).

O problema surge quando da coexistência de normas nitidamente garantistas com um Código de Processo Penal de 1941 (CPP/1941), que adotou, segundo posicionamento majoritário da doutrina, um sistema processual misto, com uma fase pré-processual, predominantemente inquisitória, e uma fase processual, de predomínio acusatório (LOPES JR, 2019, p. 43).

É na fase pré-processual que ocorrem os atos investigatórios e são produzidas praticamente todas as provas periciais. É nesse momento que emerge um dos maiores problemas contemporâneos de nossa legislação criminal, em especial a de caráter processual, que alcança o ápice no momento que o juiz utiliza provas produzidas fora do espectro do contraditório e da ampla defesa para fundamentar sentenças 
condenatórias. Destacam-se entre essas provas as periciais, que são reguladas pelo CPP/1941 e estão situadas topograficamente associada ao inquérito policial, isto é, compõem, da forma que se encontram, a investigação policial.

A partir disso, ergue-se um grande problema para o juiz, pois, ele se vê em meio ao dilema de optar entre dois caminhos espinhentos: ou abre mão da maioria das provas e corre o risco de decidir de forma inconsistente, ou aceitá-las e negar a própria CRFB/88, haja vista que na fase inquisitiva não existe contraditório pleno, bem como ausente também a ampla defesa, o que acarreta afronta fatal aos direitos e garantias fundamentais positivadas e consagradas no ordenamento jurídico pátrio utilizar prova não contradita para justificar condenações.

É nessa perspectiva que este trabalho busca estudar e abordar soluções para a questão da produção de provas na fase inquisitiva em face das garantias constitucionais relacionadas ao tema. Para isso, faz-se uso do método dedutivo na perspectiva de buscar defender a tese de um novo modelo de produção de provas periciais desvinculada da investigação policial e alicerçada sobre os pilares das garantias constitucionais.

Apresenta, ainda, as propostas de mudanças na legislação processual penal, especificamente as relacionadas à perícia criminal, a partir do projeto de lei do novo Código de Processo Penal e quais suas implicações práticas no que tange às normas constitucionais.

\section{A PROdução dA PROVA NO PROCESSO PENAL E AS GARANTIAS CONSTITUCIONAIS}

Tratar da produção da prova no processo penal é sempre algo muito delicado. Sem entrar no mérito da discussão sobre a existência de uma teoria geral do processo, a prova em matéria criminal cabe ao Estado e esse é o ponto chave, haja vista entendimento que o ente estatal responsável por tal atividade seria a acusação, resultando em uma das maiores chagas de nosso sistema processual, como será demonstrado. 
As provas eram, nos primórdios, responsabilidade das partes, que buscavam, pelos meios disponíveis elencar o maior número possível de elementos para demonstrar determinado fato, permanecendo o Estado inerte. Em virtude dos problemas constatados nesse modelo, evoluindo de uma visão privatística para concepções publicística, foi transferido às instituições religiosas, com base no direito canônico, o dever de buscar provar as alegações em relação ao crime e, consequentemente, o combate à criminalidade. Assim surge uma das mais importantes figuras de toda a evolução da humanidade relacionada à material criminal, o sistema inquisitório, que oponha diametralmente o sistema acusatório (JARDIM; AMORIM, 2018, p. 147).

A inquisição nascia com o objetivo de identificar os hereges e puni-los veementemente com a finalidade de livrar o mundo do mal. A caça às bruxas era realizada a partir de meios legais e apresentava-se como verdadeiro instrumento de justiça, haja vista ter o acusado direito a julgamento perante um juiz que o puniria, em conformidade com as leis, por seus pecados, como citam os inquisidores Heinrich Kraemer e James Sprenger, na famosa Malleus Maleficarum:

Ademais, se o julgamento e a punição dessas bruxas não fossem da alçada do juiz civil, qual seria a finalidade das leis que prescrevem a pena de morte para todas as pessoas consideradas bruxas? Ou a da que prescreve que todos aqueles prejudicam a vida de inocentes sejam lançados às feras? Pois se acha estabelecido que devem ser submetidos a interrogatório e a tortura. E que nenhum dos fiéis se deve a tais pessoas associar, sob pena de exílio e de confisco de todos os seus bens. A par de muitas outras penas que podem ser lidas a quem aprouver no código penal (KRAEMER; SPRENGER, 2017, p. 359-360).

Essa é a finalidade da inquisição, perseguir o criminoso e estabelecer meios para efetivar a punição. Mesmo com a evolução social, as mudanças de paradigmas na estrutura básica da sociedade e a prevalência do Estado, não se mudou a ideologia por trás da inquisição moderna. Mudou-se a instituição, os inquisidores, mas as bruxas ainda são as mesmas. 
Existe uma frenética busca pelo indivíduo pecador (labeling approach²) e a ânsia pela sua punição. Por isso, a sociedade brasileira presenciou até pouco tempo cenas de torturas em delegacias espalhadas por todo o território nacional, em busca da confissão do crime e de outros elementos de prova relacionados a ele. Pode não ser mais tão aberrante e escancarado como antes, mas, em lugares menos favorecidos financeiramente e longe dos holofotes, ainda são cometidas muitas barbáries e atos que não se distanciam daqueles dos realizados pela tradicional inquisição. Até porque o próprio direito penal faz uma seleção dos bens jurídicos a serem protegidos de modo a privilegiar as classes dominantes e segregar indivíduos de acordo com as suas classes sociais, afastando do sistema penal aqueles que detém poder, econômico e político, e a tratar com muito rigor indivíduos de classes subalternas (BARATTA, 1999, p. 165).

Ainda, sobre a questão da legitimação do poder, destacam-se as lições de Eugênio Raúl Zaffaroni et al, ao expor que:

O efeito mais paradoxal desta racionalização é que, ao legitimar todo o poder punitivo, o direito penal contribui para a progressiva redução do próprio poder jurídico, ou seja, do poder das agências judiciais. Todos os discursos que legitimam algum poder tratam de ampliar seu exercício através das corporações, segmentos ou setores que os elaboram. No caso do direito penal acontece o inverso: legitima o poder alheio e reduz o dos juristas. Isto é não só paradoxal, como também conduz o segmento jurídico do sistema penal a uma grave indefenso, pois o deixa com um discurso redutor de seu poder entre agências que têm uma grande vocação para o poder e um excelente treinamento para disputá-lo (ZAFFARONI et al, 2017, p. 71, grifo do autor).

O discurso da legitimação da fase inquisitória tende a ser propagado em busca de sustentar uma verdade forjada na massificação da necessidade da punibilidade do delinquente, da inibição do crime e na busca pela paz social; alicerça-se em verdadeira regra de direito, na transferência de poder, de forma a produzir discursos de verdades (FOUCAULT, 2016, p. 22).

\footnotetext{
${ }^{2}$ A labeling approach, de forma bem sintética, encontra-se ligada à criminologia crítica e estuda o papel das instituições de instâncias oficiais (polícia, juízes, instituições penitenciárias e outras) no processo de estigmatização de determinados grupos sociais a partir de mecanismos de controle e segregação no contexto da criminalidade. (BARATTA, 1999, p. 85 - 86).
} 
Em outra situação, o sistema acusatório moderno privilegia, como já foi exposto, a nítida distinção entre as atividades de acusar e julgar, transferindo a iniciativa probatória para as partes, de modo a proporcionar-Ihes tratamento igualitário, efetivando o contraditório e a ampla defesa, em procedimento oral, face a um juiz em posição de terceiro e imparcial e partindo da análise de todas as provas postas em um mesmo patamar, isto é, sem tarifa probatória (LOPES JR, 2019, p. 45).

Discorrendo sobre o sistema acusatório americano, Jacinto Nelson de Miranda Coutinho, assevera que:

Como se trata de um sistema, logo se vê que o objetivo é a busca do conhecimento (finalidade), de modo a que se possa bem decidir ou, pelo menos, decidir de forma equivocada o menos possível. Às partes, portanto, cabe, prioritariamente, a gestão da prova; e assim, garantindo a equidistância (imparcialidade) do juiz, devem carrear ao processo o conhecimento necessário para terem um julgamento positivo em relação àquilo que pretendem. A dúvida, por evidente, deve favorecer 0 acusado, em face do in dubio pro reo; e por isso à acusação se aconselha amealhar o maior conhecimento possível na direção do que pretende. Tal premissa, como é elementar, não retira da defesa a incumbência de trazer o conhecimento que lhe beneficie, quiçá desconstituindo aquele advindo da acusação. O juiz, como se percebe, resta - e deve restar - longe de tal disputa, justo para poder bem garantir a ordem estabelecida. Ele, em definitivo, não tem e não deve ter, lado (COUTINHO, 2019, p. 3, grifo do autor).

No entanto, não é conveniente regredir e retomar o antigo sistema acusatório, no qual o acusador saia em busca de provas com a finalidade de alcançar seus objetivos e os juízes (judices jurati) julgavam de acordo com sua íntima convicção; assim como também é inimaginável a possibilidade de ressuscitar o modelo inquisitorial de tarifação probatória, pois, em lenta e dolorosa evolução, consagrou-se o sistema de valoração da prova penal, tanto no Brasil como nos outros países do mundo ocidental, que ficou conhecido como livre convencimento motivado ou persuasão racional, fugindo das arbitrariedades do legislador (prova legal) bem como das do juiz (íntima convicção) ${ }^{3}$. É importante destacar ainda que o ato de valorar a prova é considerado o ponto crítico no que tange aos procedimentos processuais, já que, a partir do conjunto probatório de

\footnotetext{
${ }^{3}$ Ainda existem resquícios desses dois sistemas em nosso direito processual, a exemplo da exigência da certidão de casamento, como meio de prova legal em casos de bigamia, e do julgamento pelo tribunal do júri, em que se julga pela íntima convicção.
} 
que dispõe o juiz, será emitido um juízo de valor em relação ao fato, que resultará na imputação ou não daquilo que foi apresentado (NOGUEIRA, 2019, p. 308).

Tratando especificamente do ordenamento pátrio, adotamos um sistema misto, como já foi exposto, com uma fase pré-processual, de caráter essencialmente inquisitório, onde se limita o contraditório e a ampla defesa, e uma fase processual, essa sim com predomínio das garantias constitucionais que asseguram um processo justo, dentre elas o contraditório e a ampla defesa na composição de um devido processo legal.

No que tange à parte administrativa, cabe à autoridade policial conduzir os atos preliminares da persecução criminal sob o crivo do Ministério Público, maior interessado na fase inquisitiva, porquanto, dela extrairá todas as armas necessárias para a acusação. Na primeira fase, que ocorre na via administrativa e que ainda não corresponde a um processo judicial, faz-se a colheita de provas e, a partir disso, pode o Ministério Público oferecer a denúncia. É importante destacar que essa fase é extremamente delicada, em razão de retirar do agente o peso de responder a um processo judicial de imediato, que além de trazer todos os transtornos normais de um processo, acarreta o taxativo rótulo de acusado ou réu, por isso é inconcebível subordinar todo o controle de qualidade de confecção do conjunto probatório inicial, que ensejará o alicerce da acusação, no encargo de apenas uma das partes (acusação).

O inquérito policial, tecnicamente, não deveria passar de uma investigação, sigilosa na maioria das vezes, com a finalidade de elencar as provas necessárias da materialidade e autoria de um delito. Com isso, caberia ao Ministério Público, como exposto, direcionar ao melhor destino o caso. Isso implicaria em uma acusação fundamentada em atos de investigação, fazendo com que se iniciasse verdadeiramente o processo judicial, onde o juiz, segundo o art. 155 do CPP, formará sua convicção a partir da apreciação da prova produzida em contraditório judicial, assim como das provas cautelares, não repetíveis e antecipadas.

Ao fazer essas exceções quanto à apreciação das provas, abre-se caminho para que o juiz possa chegar à sua decisão a partir de provas produzidas sem a observância das garantias constitucionais do contraditório e da ampla defesa, isto é, possibilita-se ao juiz julgar da mesma forma que ocorria na inquisição da Idade Média, sem que o réu 
pudesse se defender, restando-Ihe esperar pela bondade e justiça do homem. Sobre isso destaca Aury Lopes Jr.:

Manteve-se, assim, a autorização legal para que os juízes e tribunais sigam utilizando a versão dissimulada, que anda muito em voga, de "condenar com base na prova judicial cotejada com a do inquérito". $\mathrm{Na}$ verdade, essa fórmula jurídica deve ser lida da seguinte forma: não existe prova no processo para sustentar a condenação, de modo que vou me socorrer do que está no inquérito.

Isso é violar a garantia da própria jurisdição e do contraditório (LOPES JR, 2019, p. 167, grifo do autor).

Outro fato que ocorre cada vez com mais frequência é a midiatização do caso e o "vazamento" das informações do inquérito policial, causando clamor popular que resulta em verdadeira condenação antecipada, o que ocasiona um estigma preconceituoso ao indivíduo que se viu investigado e sem o direito de defesa. Acarreta, de certa forma, diversas restrições, pois, a pessoa ver-se obrigada a participar de procedimentos extremamente invasivos e, não raras vezes, sofre diversos tipos de constrangimentos em seu ambiente de trabalho e familiar.

A situação é ainda pior ao se observar que as provas produzidas durante 0 inquérito comporão o processo judicial. Certo é que as provas devem ser repetidas, como reza o art. 155 do CPP, ao enfatizar que o juiz formará sua convicção a partir de provas produzidas em contraditório judicial. Contudo, algumas provas são impossíveis de repetição, como muitas das provas periciais que são realizadas em locais de crimes, onde o exame, as características do local e o tempo acarretam, consequentemente, a descaracterização completa dos elementos de prova relacionados ao fato, mas podem ser utilizadas, como regra de exceção prevista no próprio artigo supracitado, na convicção do juiz. Dessa forma, é evidente o prejuízo causado por um procedimento inquisitório que se fundamente exatamente em não possibilitar o contraditório e a ampla defesa e que constitui prova que será valorada no momento do julgamento do réu.

Tratando sobre o tema das garantias constitucionais e do inquérito policial, Tourinho Filho assevera que:

Se o inquérito policial é eminentemente não contraditório, se o inquérito policial, por sua própria natureza, é sigiloso, podemos, então, 
afirmar ser ele uma investigação inquisitiva por excelência. Durante o inquérito, o indiciado, na verdade, não passa de simples objeto de investigação. Certo que a Constituição Ihe assegura uma série de direitos, inclusive o de silenciar. Mas, quanto a ter o direito de exigir esta ou aquela prova, não. Sob esse aspecto ele não passa de objeto de investigação (TOURINHO FILHO, 2012, p. 249, grifo do autor).

A partir de tudo que foi exposto, não restam dúvidas quanto à necessidade de alternativas em relação à questão das provas não repetíveis ou não renováveis produzidas fora do processo, isto é, aquelas que são produzidas na fase de inquérito e que, por um motivo ou outro, não serão repetidas na presença do juiz. Vale destacar que isso está relacionado, na maioria dos casos, às provas técnicas, isto é, aos exames periciais que não são repetidos durante o processo judicial, restando às partes (tratando-se, neste caso, especificamente da defesa do réu) a formulação de quesito ou a nomeação de assistente técnico para formular parecer e tentar questionar os laudos periciais elaborados pelos peritos. Importante observar que ao formular quesitos em momento posterior - o tempo transcorrido entre a realização da perícia e o momento de realização dos quesitos, pode ser de anos - existe um enorme prejuízo na defesa do acusado, dado que, todos os pontos abordados deverão ser os elencados no laudo pericial e não exatamente os relacionados ao caso em concreto. Também sofre restrição semelhante o assistente técnico, haja vista que chegará às suas conclusões a partir do estudo do laudo pericial e, mais uma vez, não exatamente da análise dos vestígios do caso.

Aury Lopes Jr. afirma que esse tipo de prova deveria ser produzida sob o manto das garantias constitucionais do contraditório e da ampla defesa, a partir da fiscalização de profissionais técnicos que possam identificar, em momento próximo à realização dos exames, possíveis divergências e solicitar exames, formular quesitos, assim como arrecadar elementos suficientes para a confecção de um parecer técnico mais robusto e que possa realmente apresentar algo diretamente relacionado aos elementos de prova apreciados pelos peritos (LOPES JR, 2019, p. 165).

Assim, é nítido o caráter prejudicial da confecção de prova não repetível em procedimento essencialmente inquisitório, sem margem para contraditório e ampla defesa. Ao perceber que isso está especialmente relacionado às provas técnicas e que 
são imprescindíveis até mesmo para o processo judicial, como reza o art. 158 do CPP4, deve-se encontrar solução no sentido de proporcionar o contraditório e a ampla defesa durante a produção desse material, isto é, fazer com que a produção da prova pericial esteja de acordo com o que reza a CRFB/88.

Ainda mais relevante que todas essas questões citadas é a garantia constitucional da presunção de inocência. Não é difícil perceber que todo o exposto até - momento caracteriza uma verdadeira caça às bruxas, porque parte-se de um suspeito, que de imediato sofre as consequências do famigerado inquérito policial - e isso se considerarmos que tudo ocorre conforme o ordenamento jurídico, visto que, infelizmente, ainda existe muito desvio de finalidade, abuso de poder e outras mazelas enraizadas nas piores condutas policiais -, e, ao final, poderá arcar com resultados sociais negativos de difícil reparação, jogando por terra o princípio da presunção de inocência. Em um Estado Democrático de Direito isso é completamente abominável, deve-se supor, a acima de tudo, a presunção de inocência das pessoas, pois, "esse princípio fundamental de civilidade representa o fruto de uma opção garantista a favor da tutela da imunidade dos inocentes, ainda que ao custo da impunidade de algum culpado" (FERRAJOLI, 2014, p. 506).

Por tudo isso, afirma-se categoricamente que a produção da prova deve estar, sempre que possível, externa ao inquérito policial, servindo de base para a investigação, mas, ao mesmo tempo, disponível para a defesa poder usar de todos os meios legítimos em busca de refutá-la, ou até mesmo como mecanismo de aperfeiçoamento em busca de um processo judicial mais justo e equilibrado.

\section{DA PROVA PERICIAL}

A prova pericial é um dos pontos chaves no processo penal, assim, mesmo não existindo hierarquia entre provas, algumas não podem ser realizadas mais de uma vez, isto é, não são repetíveis ou renováveis, o que gera necessariamente seu esgotamento quando ocorre o exame.

\footnotetext{
${ }^{4} \mathrm{O}$ artigo em questão trata da indispensabilidade do exame de corpo de delito quando a infração deixar vestígios, afirmando que nem mesmo a confissão do acusado poderá supri-lo.
} 
Quando isso acontece durante a fase de processo judicial, não causa nenhum prejuízo para nenhuma das partes, visto que ocorre em observância do contraditório e da ampla defesa. No entanto, o problema reside no fato que a grande maioria das perícias criminais não ocorrem durante a fase de processo, mas sim no momento do inquérito policial.

Como o inquérito não ocorre sob o manto dos princípios constitucionais do contraditório e da ampla defesa, cria-se grave lesão ao direito do acusado no que fere sua defesa, já que será contra ele utilizado uma prova que foi produzida sob medida pela acusação (importante destacar que o inquérito policial ocorre sempre às vistas do Ministério Público, inclusive intercedendo a qualquer momento para solicitar diligências e outros atos) e fará de tudo para alcançar seu objetivo.

llusório pensar que a acusação, em caso de alguma dúvida, deixará de buscar pela condenação do acusado, pois, este é seu objeto, obrigando-se apenas quanto ao fumus commissi delicti, à existência de indícios razoáveis de autoria e materialidade e à justa causa, isto é, necessária apenas a existência da possibilidade razoável quanto à autoria e materialidade do ilícito - do contrário, não existiria absolvição após a denúncia -, mas que, para o juiz, é completamente insuficiente para fundamentar uma sentença condenatória. Aury Lopes Jr., ao tratar da parcialidade do Ministério Público, expõe que:

Como já explicamos, não existe parte imparcial; isso é uma construção equivocada e que não encontra qualquer amparo lógico ou semântico. $O$ MP é, no processo penal, uma parte artificialmente criada e construída para ser o contraditor natural do sujeito passivo, retirando poderes do juiz para, com isso, criar condições de possibilidade para que se estabeleça uma estrutura dialética e um processo acusatório. Na exata definição de WERNER GOLDSCHMIDT, quando mais parcial forem as partes, mais imparcial é o juiz (esse, sim, estruturado e constituído a partir da concepção jurídica de terzietà/imparcialidade).

Sem esquecer, ainda, a precisa definição de GUARNIERI, quando afirma que acreditar na imparcialidade do Ministério Público é uma ilusão. A mesma ilusão de confiar ao lobo a melhor defesa do cordeiro (LOPES JR., 2019, p. 321-322, grifo do autor).

Consciente dessa parcialidade, deve-se buscar mecanismos de fazer com que a defesa alcance as provas técnicas ainda na fase de inquérito e busque, desde já, descaracterizar os elementos apontados pela acusação, minimizando, assim, as falhas 
processuais que surgem quando são aceitas denúncias sem um mínimo de contraargumentações, mesmo em relação ao trabalho pericial.

Os exames periciais compreendem uma gama de conhecimento extremamente abrangente e, com o avanço cada vez mais rápido da ciência, muitos métodos ou técnicas periciais são incorporados ao cotidiano dos trabalhos dos cientistas periciais. Além das áreas tradicionais, como a medicina, biologia, química, física e engenharia, muitas outras estão surgindo como verdadeiras ciências a contribuir com o judiciário. Em relação a estas existe um esforço doutrinário no sentido de alertar quanto à necessidade de o juiz averiguar métodos adequados de valoração da prova. Sobre o assunto, Knijnik assinala que:

[...] atualmente, o conceito de prova pericial estende-se para vários setores de investigação e conhecimento, os quais, sem dúvida, subsumem-se a um conceito ampliado e moderno de ciência, dando lugar às perícias psicológicas, econômicas - v.g ., no julgamento de atos de concentração pelo CADE, contábeis e antropológicas, que também reclamam métodos adequados de valoração pelo juiz, sob pena de desviar o processo, estatal ou arbitral, de uma resolução justa (KNIJNIK, 2017, p. 110-111).

Porém, não basta que o empenho seja apenas para a apreciação e valoração da prova pericial durante a fase de processo. Em sede de processo penal, nunca é excesso lembrar que a maioria das perícias ocorre durante o inquérito policial, distante do controle direto do judiciário e da defesa, o que reduz consideravelmente as possibilidades de constatação de erro durante a realização dos exames ou mesmo do emprego de técnicas e métodos inconsistentes. Alguns procedimentos periciais são tão complexos que qualquer falha durante as etapas de realização do exame - desde a amostragem, coleta, e outros procedimentos preliminares até o exame propriamente dito - existe a possibilidade de resultados equivocados ou mesmo inacessíveis, em virtude da inutilização do material. O caso é tão complexo que o Ministério da Justiça, através de um Procedimento Operacional Padrão da Perícia Criminal, destacou como ponto crítico as metodologias empregadas em procedimentos de coleta de material biológico em local de crime para exame de genética forense, como segue: 
As metodologias utilizadas nos exames genéticos são muito sensíveis, de modo que contaminações mínimas podem prejudicar os exames. Deste modo, o perito oficial deve tomar todo o cuidado para evitar a deposição acidental do seu próprio material biológico sobre o vestígio, não devendo, portanto, manipular ou se encostar no mesmo sem luva, nem falar, espirrar ou tossir sobre ou próximo do mesmo sem máscara (BRASIL, 2013, p. 63).

Como é facilmente constatado, a ausência do contraditório e da ampla defesa durante a realização dos exames periciais resulta em grandes prejuízos para a defesa. Assim, é relevante o acompanhamento desde o início pelos profissionais elencados pelo acusado ou defesa no intuito de efetivar maior controle na produção da prova pericial. Além do questionamento referente aos procedimentos adotados durante a realização dos exames, pode-se, inclusive, abrir discussões quanto aos testes realizados e, além de tudo isso, identificar, em situação posterior, se o que foi coletado encontra-se de alguma forma comprometido para novos exames, em caso de possibilidade de repetição, isso porque "se o material não se reveste de suas características originais, os resultados alcançados podem ser comprometidos quando comparados com os exames iniciais" (CÂNDIDO; DIAS FILHO, 2016, p. 347). Nesse caso, como o juiz terá dificuldades para identificar se ocorreu erro no momento de realização dos exames iniciais ou a amostra de contraprova sofreu modificações que resultaram em resultados diferentes, a defesa é a maior interessada em constatar isso e pode ajudar o magistrado nessa tarefa.

O acompanhamento da defesa desde o início dos exames periciais (no exercício do seu direito de ampla defesa) poderia resultar na identificação de métodos que são cientificamente inconsistentes, isto é, constitui-se mais uma forma de controle no combate à chamada "junk science"5 (MANZANO, 2011, p. 197). Com a perícia inserida no contexto do inquérito policial fica praticamente impossível tal medida de controle, resultando em casos como as condenações que por décadas foram fundamentadas nas provas periciais de detecção de resíduos de tiro, produzidas por métodos completamente imprecisos, e eram utilizadas sob a falácia do cotejamento com as

\footnotetext{
5 A chamada junk science constitui-se de procedimentos que são, aparentemente, revestidos por métodos e metodologias científicos, mas não possuem rigor científico e resultam em pesquisas fraudulentas e enganosas, mas que podem iludir o homem médio.
} 
provas produzidas no processo. Mesmo com enorme possibilidade de erro, apenas recentemente esses exames caíram em desuso, como exposto abaixo:

A detecção de resíduos de tiro (GSR) nos Institutos de Criminalística no Brasil ainda é realizado por testes químicos (via-úmida) para deteç̧ão de resíduos orgânicos, especialmente o método de Griess (revelação de nitritos oriundos da pólvora combusta), ou inorgânicos para deteç̧ão de chumbo (rodizonato de sódio), chumbo e bário (iodeto de trifenilmetilarsênio) e cobre (ditio-oxamida). Embora eficientes, estes métodos não garantem que a natureza dos elementos químicos detectados seja proveniente de disparo de arma de fogo, uma vez que estes são facilmente gerados por diversas atividades ocupacionais. Em países desenvolvidos, a análise por microscopia eletrônica de varredura (MEV)/EDS é um método rotineiro, mas no Brasil praticamente não é utilizada. A detecção de GSR por MEV/EDS baseiase na análise da morfologia esférica característica e da composição química (presença de $\mathrm{Pb}, \mathrm{Ba}$ e $\mathrm{Sb}$ ) da partícula. Esse tipo de análise permite a distinção inequívoca de partículas oriundas de tiro e de origem ocupacional, com um risco praticamente nulo de falso positivo e possibilidade de contra-prova, caso seja necessário, inclusive por outras metodologias, uma vez que é um método não destrutivo (PINTO et al, 2005, p. $7-8$, grifo nosso).

Mas esse não é o único problema resultante da falta de controle de qualidade da prova científica, porquanto muitos são os parâmetros e critérios que devem ser analisados para certificar confiabilidade a ela, a exemplo dos procedimentos relacionados à cadeia de custódia que devem ser impecáveis. Apresentando trabalho sobre estudos de casos em balística forense, Domingos Tocchetto relata, em um deles, que:

Através do ofício no 1.507/2001, datado de 25/08/2001 foi solicitado o Exame de Pólvora Combusta nas Mãos de R. R. M., visando atender o DPC M. R. B. - 5 a Seccional Urbana de Polícia Civil (Laudo de Exame no 024/2001). O material examinado pelos Peritos foi Duas gazes embebidas em solução de ácido acético 10\% contendo material coletado das mãos direita e esquerda da pericianda. Uma questão importante, que não consta do Laudo de Exame no 024/2001, é a origem destas duas gazes, isto é, quem colheu os resíduos das mãos da acusada, quando e onde foi feita esta coleta e como foram acondicionadas e enviadas as duas gazes, para a realização de pólvora combusta (TOCCHETTO, 2018, p. 198, grifo do autor).

O caso citado acima é de uma ré que foi "indiciada, denunciada e pronunciada por homicídio, motivo pelo qual, através do seu defensor, solicitou a elaboração de um Parecer Técnico" (TOCCHETTO, 2018, p. 191), o que representa extrema ofensa a 
diversos princípios constitucionais, dentre eles o da presunção de inocência, haja vista ter sido oferecida denúncia fundamentada em provas que se utilizavam de métodos inconsistentes e exames periciais realizados sem os devidos cuidados relacionados à cadeia de custódia.

Dessa forma, sustenta-se que a perícia criminal não deve permanecer inserida no inquérito policial, mas sim, constituir verdadeira instituição autônoma e independente, e vincular-se ao órgão judicial, disponível aos interessados (polícia civil, Ministério Público e defesa) desde o início e sob a guarda de um juiz (juiz guardião ou de garantias).

Isso faria com que a prova pericial alcançasse um standard probatório ${ }^{6}$ de confiabilidade para, somente após reconhecida como prova verdadeiramente científica, ser admitida no processo. Dessa forma, o simples fato de tratar-se de um perito oficial não é critério suficiente para garantir que a prova tenha sido produzida dentro dos rigores do método científico e que seja prova livre de inconsistências; faz-se mister que a produção dela seja acompanhada pela defesa, como corolário da ampla defesa. Em seguida, a prova deve ser submetida à apreciação de um juiz guardião, encontrando-se assim amparada pelos princípios constitucionais do contraditório e da ampla defesa (fundamental em casos de provas não repetíveis), fazendo com que apenas provas confiáveis sejam admitidas no julgamento, resultando, consequentemente, no fortalecimento dos princípios da presunção de inocência, devido processo legal, economicidade processual, paridade de armas e na busca que só sejam aceitas denúncias fundamentadas em provas legítimas (KNIJNIK, 2017).

Por tudo isso, a perspectiva da prova pericial não é exatamente a verdade formal ou material, mas a fidelidade com a realidade encontrada no momento dos exames, bem como as conexões lógicas entre o material examinado e determinado fato. Assim, o perito criminal encontra-se vinculado à verdade dos fatos no momento da realização

\footnotetext{
${ }^{6}$ Os standards de prova não se resumem apenas à prova pericial, muito pelo contrário, estendem-se a todas as provas que são elencadas no processo, conferem, sim, a elas um nível mínimo de credibilidade para que o juiz as aceitem como elemento de cognição no momento da decisão, isto é, a prova deve possuir robustez suficiente para atingir um padrão adotado como critério de confirmação de uma hipótese, fazendo com que o juiz emita manifestação no sentido de afirmar que o material probatório apresentado na tese da acusação conseguiu atingir grau suficiente para afastar a presunção de inocência, isto é, se atingiu o standard probatório (RAMALHO JUNIOR; NEVES, 2019, p. 144).
} 
da perícia e, a partir daquilo que constata, faz diversas aferições cognitivas quanto à possibilidade ou não de determinado fato, diga-se, trabalha com possibilidades, sendo a prova processual um esforço interpretativo em relação à verificação de hipóteses com o objetivo de convencer o juiz.

Não é que a prova seja resumida à retórica, um conjunto de argumentos vazios que podem, de alguma forma, convencer alguém de algo, não é nesse sentido que se defende que ela seja um esforço interpretativo, até mesmo pela própria colocação do termo, sustenta-se que é uma dedução lógica e aceitável do acontecimento de determinado fato a partir da análise de todo um conjunto de elementos. Dessa forma, o resultado do trabalho pericial torna-se prova stricto sensu quando é gerido pelas partes (acusação e defesa) e consegue, partindo do que foi colocado, alcançar o convencimento do ouvinte (juiz). Deduz-se de tudo isso que, se o resultado do trabalho pericial é obtido por meio da utilização de técnicas ou métodos falhos, imprecisos ou inconsistentes é impossível esperar que chegue ao juiz uma prova legítima.

\subsection{A prova pericial no Código de Processo Penal}

O destinatário da prova é, certamente, o juiz, mas o maior interessado nela, sem qualquer sombra de dúvida é o acusado, posto que, a partir do grau de convencimento do juiz em relação a determinado fato, pode resultar em uma sentença condenatória, que recairá sobre aquele que foi imputado. Nessa perspectiva, sustenta-se que a captura psíquica do juiz é a melhor solução para o processo penal acusatório face às garantias constitucionais e que isso pode reduzir as margens de subjetividade engendradas no processo penal do inimigo (KHALED JR.; DIVAN, 2019, p. 405).

O problema é que da forma que a prova é constituída no atual sistema processual brasileiro, a captura psíquica do juiz recai sobre elementos que são produzidos na fase pré-processual sem qualquer questionamento por parte da defesa. Esses elementos, como já foi exposto, são as chamadas provas não repetíveis ou renováveis que, com limitadas exceções, constituem provas elencadas a partir de exames periciais. 
O problema nisso tudo é que a gestão dessas provas está exclusivamente com a acusação, isto é, todo o material probatório constituído durante a fase inquisitiva fica à disposição da acusação e é utilizado sempre de forma ao convencimento do juiz quanto à condenação do acusado.

A perícia, no atual contexto, encontra-se dentro da estrutura da polícia civil, nos estados, e da polícia federal, a nível de União. Com isso, cria-se a cultura da investigação a cargo da perícia, o chamado perito investigador, com situações, no mínimo, equivocadas de que a prova pericial é para condenar, como exposto abaixo:

A falta de uma perícia aparelhada, bem remunerada e treinada, gera um elo frágil na obtenção das provas necessárias a um julgamento justo, enfraquecendo assim o processo de aplicação da justiça. Verifica-se esta situação ao se analisar as notícias de inúmeros julgamentos que acabaram em impunidade dos réus por falta de provas consistentes. Infelizmente o resultado é o aumento da "sensação de impunidade" (VELHO; COSTA; DAMASCENO, 2013, p. 8, grifo do nosso).

É fácil notar na passagem o ranço inquisitivo que é essência da investigação policial. Por isso, a inserção da perícia criminal no contexto da investigação policial é mais uma forma de controle no que tange ao sucesso da pretensão punitiva, isto é, quando criado o CPP/1941, era fundamental estruturar os meios possíveis de garantir a punição, reduzir ao máximo as lacunas da impunidade; isto resume a ideologia reinante em um código que utilizou o modelo estritamente inquisitório, como destaca Lopes Jr.:

Compreende-se assim que o modelo constitucional é acusatório, em contraste com o CPP, que é nitidamente inquisitório.

O problema situa-se, agora, em verificar a falta de conformidade entre a sistemática prevista no Código de Processo Penal de 1941 e aquela da Constituição, levando a que afirmemos, desde já, que todos os dispositivos do CPP que sejam de natureza inquisitória são substancialmente inconstitucionais e devem ser rechaçados.

A gestão da prova deve estar nas mãos das partes (mais especificamente, a carga probatória está inteiramente nas mãos do acusador), assegurando-se que o juiz não terá iniciativa probatória, mantendo-se assim suprapartes e preservando sua imparcialidade (LOPES JR., 2019, p. 95 - 96).

Trilhando o mesmo caminho, Eugênio Pacelli assevera que "o Direito Processual Penal brasileiro não pode mais ser aplicado com base na estrutura do ainda vigente CPP/1941 [...] a Constituição da República, de há muito, lançou novas luzes sobre a 
matéria" (PACELLI, 2015, p. 35). Defende o autor que é fundamental que todos os atos relacionados à material penal e processual penal sejam reguladas a partir da observância das garantias constitucionais.

Contudo, na prática existe uma quimera processual ao permitir que o juiz utilize elementos do inquérito, na formação de seu livre convencimento, em conjunto (cotejados) com provas que passaram pelo crivo do contraditório e da ampla defesa (LIMA, 2019, p. 136). Como bem esclarece Aury Lopes Jr. (2019), se os elementos do inquérito são necessários para que o juiz chegue a uma conclusão, diga-se de sentença condenatória, então é perfeitamente lógico concluir que as provas que passaram pelo crivo do contraditório e ampla defesa não foram suficientes para isso; e voltamos ao "ademais, se o julgamento e a punição dessas bruxas não fossem da alçada do juiz civil [criminal], qual seria a finalidade das leis" (KRAEMER; SPRENGER, 2017, p. 359), pois é crucial reduzir a sensação de impunidade, sob qualquer pretexto, mesmo atropelando, em todos os atos que resultem em restrição de direitos - seja inquisitivo ou processual -, diversas garantias constitucionais que asseguram ao cidadão um julgamento justo, a presunção de inocência, o direito ao contraditório e a ampla defesa. Não, essa não é a essência da sociedade moderna, pelo contrário, deve-se assegurar todas as garantias possíveis para resguardar a dignidade da pessoa humana, tendo em vista que:

In dubio pro reo, ou, em bom vernáculo, na dúvida prevalece a incerteza. E, com ela, em um Estado Democrático de Direito, a interpretação pautada pelos postulados da vedação de excesso (do poder) e da máxima efetividade dos direitos fundamentais, impondo, em tais situações, a não condenação (PACELLI, 2015, p. 34, grifo do autor).

A partir disso, faz-se mister pensar em mudar toda a estrutura da fase préprocessual, retirando a produção de provas periciais do âmbito policial e colocando-a sob a guarda de um juiz - denominado pela doutrina de juiz de garantias. As mudanças devem iniciar a partir da disposição topográfica da perícia no CPP, criando uma seção específica para ela e garantindo independência administrativa e funcional.

No atual modelo, 0 art. 6 do CPP determina que, logo que tomar conhecimento da infração penal, a autoridade policial deverá se deslocar para o local e assegurar o estado das coisas até a chegada dos peritos criminais. Isso é um problema grave, 
principalmente por destoar em grande parte da realidade, isto é, o que ocorre na maioria das vezes é que a Polícia Militar é a primeira a chegar e comunica o fato à delegacia, que, logo em seguida, comunica, sem qualquer formalidade, ao órgão pericial. Somente após a chegada dos peritos criminais e constatada de fato a infração, é que a autoridade policial determinada pelo caput do art. 6ํㅗ se dirige para o local.

Dessa forma, nada mais lógico que alterar o comando e determinar que a averiguação da infração seja feita pelo perito criminal. Ao constatar realmente a prática de crime, aciona-se todo o aparato policial afim de iniciar os primeiros procedimentos de investigação. Isso facilitaria a questão da preservação e isolamento do local, pois, seria menos pessoas transitando pela cena antes da chegada dos peritos criminais, como enfatiza Badaró:

A preservação do local do crime é fundamental para a colheita de elementos de informações que poderão ser muito úteis para a descoberta da forma de cometimento do delito e de sua autoria. Infelizmente, na prática, muitas vezes não se preserva o local do crime adequadamente, de forma que, quando o perito chega à cena delitiva, muito já se perdeu em termos de investigação (BADARÓ, 2018, p. 140, grifo do autor).

Como o exame de corpo de delito é indispensável nos casos em que a infração deixar vestígios, a perícia necessariamente deve comparecer ao local e realizar todos os atos necessários ao exame e isso não impede que, paralelamente, a investigação policial aconteça. O que não deve acontecer é a vinculação direta da perícia criminal aos atos de investigação da polícia civil ou federal, dependendo do caso.

Ao assumir essa postura, o perito não sendo mais um integrante direito do inquérito policial, tem-se uma mudança ideológica da própria perícia no momento de interpretação dos elementos técnicos examinados, acaba-se com os motivos pelos quais o inquérito ainda permanece no processo, isto é, se a prova pericial - que compreende praticamente todas as provas não repetíveis - não está no inquérito, não existem motivos para que ele (inquérito) não seja excluído do processo judicial e, além de tudo isso, como a prova pericial não é na sua essência ato investigatório, pode, o juiz guardião (juiz de garantias) perfeitamente assegurar o contraditório e a ampla defesa, eliminando definitivamente a possibilidade de julgamento com fundamento em provas que não passaram pelo crivo dessas garantias. 
Além de tudo, o órgão pericial atuando de forma autônoma, independente da figura do delegado de polícia, evitaria procedimentos investigativos sem a devida instauração do inquérito policial, uma vez que é:

[...] prática reprovável e ilegal a investigação sem formalização dos atos. Mas quando se pretende redução da atividade burocrática, afinal, todo inquérito precisa ser remetido a juízo, não registrar pode ser estratégia dominante, assim como o não registro diminui as estatísticas de crimes. Há incentivo para se evitar o registro e melhorar o índice de criminalidade artificialmente (ROSA, 2017, p. 415-416).

Assim, a iniciativa de comunicação do delito constitui mais um motivo para o órgão pericial não permanecer inserido no contexto policial, bem como vinculado a secretarias, como ocorre nos casos em que a perícia resolve "sair" da polícia, mas continua sob o comando de um secretário que exige fidelidade dos atos periciais em relação aos comandos do delegado de polícia.

\section{PROPOSTA DE UM NOVO MODELO DE ORGANIZAÇÃO DA PERÍCIA CRIMINAL E PRODUÇÃO DA PROVA PERICIAL}

A perícia criminal faz uso de diversas áreas da ciência para realizar pesquisas e emitir juízo de valor sobre fatos que ensejam perturbações no mundo jurídico. $O$ responsável por isso é, normalmente, um perito oficial ${ }^{7}$. Em muitos casos, esse profissional depara-se com instituições desprovidas de equipamentos apropriados para a realização de exames confiáveis, em casos mais drásticos, chega a faltar materiais básicos de trabalho, como reagentes químicos, algodão, luvas e máquinas fotográficas (COTRIM, 2014).

Considerando o melhor dos cenários, com toda a tecnologia disponível, ainda assim a ciência dependerá da postura do cientista, como aponta Marcelo Ribeiro Uchôa:

\footnotetext{
7 O art. 159 do CPP determina que o exame de corpo de delito será realizado por perito oficial, isto é, aquele que possui curso superior e foi aprovado em concurso público para o cargo. Contudo, no primeiro parágrafo, dispõe que o exame pericial poderá ser realizado por duas pessoas idôneas, com formação superior, com preferência que seja formação na área específica do exame, sempre que não existir no local o perito oficial.
} 
Nesta conjuntura, o papel do bom cientista, a bem do melhor e mais condizente para regras de bem-estar, precisa ser de independência e altivez. [...] ciências são suscetíveis a interferências humanas, que, por sua vez, são suscetíveis a jogos ideológicos. [...] face a tudo isso deve buscar imprimir em si e nos seus pares uma visão crítica capaz de mudar-lhes a postura diante das imposições externas, e mesmo de suas próprias vaidades e aspirações (UCHÔA, 2014, p. 13).

É fácil perceber, como já foi demonstrado, que profissionais vinculados à atividade policial tem uma perspectiva de investigar e apontar os elementos necessários à punição do acusado. Contudo, isso não é o que se espera da perícia, haja vista existir a ideia de que ela é ciência e não se contamina pela ideologia inquisitiva. Como sustenta o autor, é importante entender que até mesmo a ciência é suscetível a jogos ideológicos, assim, é evidente que a perícia não deve continuar inserida no contexto policial e que o trabalho científico desenvolvido pelos profissionais que a compõem seja liberto do dogma inquisitório da acusação.

Nesse panorama, propõe-se um novo modelo de produção da prova pericial, calcada em princípios constitucionais e condizente com um Estado Democrático de Direito. A perícia criminal deve atuar independentemente da polícia civil, inclusive sem qualquer rotulação de polícia, para focar verdadeiramente em pesquisas científicas fundamentadas na busca pelo desenvolvimento da melhor ciência, isto é, sem a preocupação de que o resultado alcançado não resultará em uma prova para a condenação de alguém, ciente da necessidade de zelar pela dignidade da pessoa humana, reconhecendo os direitos constitucionais de toda e qualquer pessoa suspeita ou acusada de algum crime, possibilitando, dessa forma, condição de igualdade entre defesa e acusação perante os órgãos periciais.

O modelo proposto retira a perícia da polícia e a coloca em posição linear com o juiz, consolidando uma conexão direta entre o trabalho pericial e o controle judicial. É importante destacar que não se defende a figura do juiz inquisitivo, muito pelo contrário, o juiz guardião ou de garantias atua, nesse modelo, como o responsável pelos atos necessários à acusação e defesa, de modo a exercerem o controle sobre as atividades periciais de forma igualitária, isto é, que tanto a defesa quanto o Ministério Público 
possam atuar positivamente no sentido de fiscalizar e controlar ${ }^{8}$ a produção da prova científica, destarte poderão, desde o início, solicitar esclarecimentos sobre os métodos e procedimentos, questionar sobre possíveis falhas e formular quesitos que entenderem necessários às suas teses. Mas tudo isso por meio do juiz, nenhum contato entre o perito e a defesa ou acusação, principalmente para evitar possíveis contaminações e efetivar verdadeiramente o contraditório (DUCLERC, 2016, p. 62).

A produção da prova pericial, nessas condições, proporcionará a completa retirada do inquérito policial dos autos do processo judicial, pois, além dela, apenas algumas raras exceções não podem ser repetidas na fase processual. Nesse modelo, superada todas as fases de produção e submetido ao contraditório e a ampla defesa, o laudo pericial é encaminhado ao juiz que o disponibilizará para que as partes façam o melhor uso. Destaca-se que, mesmo após a confecção do laudo, nada mudaria quanto à possibilidade de novos questionamentos ou mesmo a não aceitação pelo juiz, seja no todo ou em parte, isto é, não se defende a criação do perito-juiz no direito brasileiro.

Para alcançar esses objetivos, é necessário que ocorram mudanças significativas no CPP/1941, reorganizando alguns procedimentos relacionados ao inquérito policial, principalmente aqueles que tratam da vinculação dos procedimentos periciais à figura do delegado de polícia, bem como efetuar mudanças na própria CRFB/88, no sentido de criar uma instituição pericial independente e autônoma, não só administrativa, mas, principalmente, criar mecanismos para a instituição elaborar sua proposta orçamentária e incentivar o aparelhamento tecnológico e a capacitação dos peritos. Assim, a nível constitucional, é mais sensato retirar a perícia oficial do rol do art. 144, que trata da segurança pública, e deslocá-la para o interior do capítulo que trata das funções essenciais à Justiça.

\footnotetext{
${ }^{8}$ Ao defender que as partes podem controlar a produção da prova pericial não se defende que poderão influenciar nos resultados, pois são coisas distintas. O controle é exercido na medida em que existe averiguação dos procedimentos e equipamentos, acompanhamento das análises por pares e outros procedimentos realizados com a finalidade de garantir a qualidade dos resultados alcançados.
} 


\section{CONCLUSÃO}

A maioria das provas periciais não são repetíveis ou renováveis e são produzidas exclusivamente durante a fase de inquérito policial. Por determinação legal, é obrigatório o exame pericial quando a infração deixar vestígios, assim sendo, ocorrerá a produção de uma prova que comporá os autos do processo judicial. A partir do momento que o juiz utiliza uma prova que foi produzida sem respeitar as garantias constitucionais do contraditório e da ampla defesa, incorre em violação da própria jurisdição.

Destarte, deve-se buscar meios de efetivar todas as garantias constitucionais sem perder de vista a realidade processual, isto é, submeter todas as provas - ou pelo menos a maioria maciça - ao crivo da defesa e retirar por completo o inquérito policial dos autos do processo, sem prejudicar os meios de acusação.

Para isso, a melhor saída é constituir um novo modelo de órgão pericial, autônomo e independente da polícia, inclusive com formação dos peritos criminais em ambiente próprio, sem a ideologia da perseguição inquisitiva. Assim, sem a necessidade dos requisitos impostos ao inquérito policial, a prova pericial pode ser plenamente colocada à disposição da acusação e da defesa, para exercerem todos os meios de controle sobre ela, circunstância que efetiva as garantias constitucionais e legitima o devido processo legal.

Mas isso só será possível a partir do momento em que a perícia criminal for reconhecida como instituição permanente e essencial à justiça, seja disponibilizada para ela instrumentos efetivos de obtenção de recursos para aparelhamento e aperfeiçoamento dos peritos, além de integrá-la a um sistema que preze pelo respeito aos princípios basilares da ciência e que seja locupletado pela atuação da defesa e da acusação em situação de igualdade, sob o manto das garantias constitucionais.

\section{REFERÊNCIAS}

BADARÓ, Gustavo Henrique. Processo Penal. 6. ed. rev. atual e ampl. São Paulo: Thomson Reuters Brasil, 2018. 
BARATTA, Alessandro. Criminologia crítica e crítica do direito penal: introdução à sociologia do direito penal. Tradução Juarez Cirino dos Santos. 2. ed. Rio de Janeiro: Freitas Bastos: Instituto Carioca de Criminologia, 1999.

BRASIL. Secretaria Nacional de Segurança Pública. Procedimento Operacional Padrão: perícia criminal. Brasília: Ministério da Justiça, 2013.

CÂNDIDO, Ian Marques; DIAS FILHO, Claudemir Rodrigues. Coleta e preservação dos vestígios biológicos. In: DIAS FILHO, Claudemir Rodrigues; FRANCEZ, Pablo Abdon da Costa (Org.). Introdução à biologia forense. Campinas: Millennium Editora, 2016.

COTRIM, Maria José. Em protesto, peritos e legistas entregam cargos ao Governo e alegam falta de estrutura e até reagentes vencidos para perícia. Disponível em: $<$ https://conexaoto.com.br/2014/04/09/em-protesto-peritos-e-legistas-entregam-cargosao-governo-e-alegam-falta-de-estrutura-e-ate-reagentes-vencidos-para-pericia>. Acesso em: 15 jul. 2019.

COUTINHO, Jacinto Nelson de Miranda. Plea bargaining no projeto anticrime: crônica de um desastre anunciado. Boletim IBCCRIM. São Paulo, ano 27, n. 317, Edição Especial, p. 2-5, abr. 2019.

DUCLERC, Elmir. Introdução aos fundamentos do direito processual penal. Florianópolis: Empório do Direito, 2016.

FERRAJOLI, Luigi. Direito e razão: teoria do garantismo penal. Tradução Ana Paula Zomer Sica (et al). 4. ed. rev. São Paulo: Editora Revista dos Tribunais, 2014.

FOUCAULT, Michel. Em defesa da sociedade: Curso no Collège de France. Tradução Maria Ermantina de Almeida Prado Galvão. 2. ed. São Paulo: Editora WMF Martins Fontes, 2010. (Coleção obras de Michel Foucault).

JARDIM, Afrânio Silva; AMORIM, Pierre Souto Maior Coutinho de. Direito processual penal: estudos, pareceres e crônicas. 15. ed. rev. e ampl. Salvador: Editora Juspodivm, 2018.

KHALED JR, Salah H.; DIVAN, Gabriel Antinolfi. A captura psíquica do juiz e o sentido da atividade probatória no processo penal contemporâneo. Revista Brasileira de Ciências Criminais. V. 156. p. 395 - 423, jun. 2019.

KNIJNIK, Danilo. Prova pericial e seu controle no direito processual brasileiro. São Paulo: Editora Revista dos Tribunais, 2017.

KRAEMER, Heinrich; SPRENGER, James. O martelo das feiticeiras: Malleus maleficarum. Tradução de Paulo Fróes. 28. ed. Rio de Janeiro: Record, 2017. 
LIMA, Renato Brasileiro de. Manual de processo penal. 7. ed. rev. ampl. e atual. Salvador: Editora JusPodivm, 2019. Único V.

LOPES JR, Aury. Direito processual Penal. 16. ed. São Paulo: Saraiva Educação, 2019.

MANZANO, Luís Fernando de Moraes. Prova pericial: admissibilidade e assunção da prova científica e técnica no processo brasileiro. São Paulo: Atlas, 2011.

NOGUEIRA, Rafael Fecury. Evolução histórica dos sistemas de valoração da prova penal: continuamos evoluindo? Revista Brasileira de Ciências Criminais. V. 156. p. $307-352$, jun. 2019.

PACELLI, Eugênio de Oliveira. Curso de processo penal. 19. ed. rev. atual. São Paulo: Atlas, 2015.

PINTO, André Luiz et al. Avaliação de um procedimento alternativo para coleta e análise por MEV/EDS de resíduos de provenientes de disparo de arma de fogo.

Revista Científica do Departamento de Polícia Técnica da Secretaria de Segurança Pública da Bahia. Salvador, v. 2, n. 6. p. 7 -11, dez. 2005.

RAMALHO JUNIOR, Elmir Duclerc; NEVES, Luiz Gabriel Batista. Punição, verdade e prova: perspectiva crítica e transdisciplinar. Revista Brasileira de Ciências Criminais. V. 156. p. $141-163$, jun. 2019.

ROSA, Alexandre Morais da. Guia do Processo Penal conforme a teoria dos jogos. 4. ed. rev. atual. e ampl. Florianópolis: Empório do Direito, 2017.

TOCCHETTO, Domingos. Estudos de casos em balística: se os mortos falassem os vivos não mentiriam. 2. ed. rev. ampl. e atual. Campinas: Millennium Editora, 2018.

TOURINHO FILHO, Fernando da Costa. Processo penal. 34. ed. rev. São Paulo: Saraiva, 2012. $1 \mathrm{~V}$.

UCHÔA, Marcelo Ribeiro. Justiça, direito e cidadania. Rio de Janeiro: Lumen Juris, 2014.

VELHO, Jesus Antônio; COSTA, Karina Alves; DAMASCENO, Clayton Tadeu Mota. O local de crime e suas interfaces. In: criminosa. Campinas: Millennium Editora, 2013. Locais de crime: dos vestígios à dinâmica

ZAFFARONI, Eugenio Raúl. et al. Direito Penal Brasileiro. 4. ed. Rio de Janeiro: Revan, 2017. I V. 